\title{
The Use of Video as a Media to Improve Students' Vocabulary Mastery
}

\author{
Yeni Mardiyana Devanti ${ }^{1}$ \& Ana Rizqi Amalia ${ }^{2}$ \\ ${ }^{1}$ Universitas Muhammadiyah Jember \\ ${ }^{2}$ SMP Muhammadiyah 1 Jember \\ (yenimardiyana@unmuhjember.ac.id )
}

\begin{abstract}
The objective of this Classroom Action Research was to improve students' vocabulary mastery by using video as a media in teaching and learning process. It covered four stages of activities, they were planning, implementing, observing, and reflecting of the action. The subject of this research was class VII C of SMP Muhammadiyah 1 Jember. In this research, the primary data were collected from the vocabulary test while the observation check list as supporting data was taking during the teaching and learning process. Video as a media of teaching and learning vocabulary improved students vocabualry mastery in two cycles from the percentage of students scored $\geq 70$, was $69 \%$ in cycle 1 to $80 \%$ in cycle 2 , it also improved students' active participation from 55\% in cycle 1 to $77 \%$ at the end of the cycle 2 . Based on the research result, it can be concluded that the video as a media of teaching English vocabulary was able to improve the seventh grade students' vocabulary mastery and students's active participation.
\end{abstract}

Keywords: Vocabulary mastery, video.

The Government of Indonesia in this case the minister of education is trying to develop an effective way to master English due to the increasing need of English as a means of communication. This development is seen on the regulations of English Language development written in Curriculum 2013 especially in the Ministrial Regulation of National Education No. 22 of 2016 about Process Standard of Elementary and High School Education (2016: 3). The goverment prepares students to express their knowledge, mind, feeling and develop their knowledge of sciences, technology and culture by using English. Therefore, English becomes a subject learning from Junior High School to university. Thornbury (2002:13) states "without vocabulary nothing can be conveyed". Based on that statement, students's vocabulary must be improved. Hence, understanding vocabulary will help the students to express their mind, felling, and develop their knowledge of sciences, technology and culture in order to achieve the functional level easily.

The importance of vocabulary mastery has become crucial factor for students to help them learn a foreign language. However, it was found through a preliminary study that the students of SMP Muhammadiyah 1 Jember were still having quite low vocabuary mastery. Based on the information from an English teacher in the preliminary study, and the pre test it was found that most of students at seventh grade class have difficulties in remembering the meaning, pronunciation, and spelling of words making it hard for them 
to express their thoughts, both spoken and written.

In attempt to overcome the problem, the use of visual media was assumed to be an appropriate method to help the teacher and students to solve their problem in teaching and learning vocabulary because using a visual media in classroom will make the teaching and learning process more alive and can attract the students' attention to the lesson. Therefore, the use of video as a media is chosen to improve the students' vocabulary mastery. Hence, the students will not only enjoy watching the movies but also learn words used in the dialogue. In addition, a study (Harji, et al., 2010) supported the theory saying that video gives better contribution to the teaching and learning process in studying English vocabulary. A classroom action research is an appropriate way to be undertaken and watching movies become an effective method that could be used by teacher to improve students' vocabulary mastery. Therefore, a classroom action research entitled "The use of video as a media to improve students's vocabulary mastery at SMP Muhammadiyah 1 in the 2018-2019 academic year" was conducted.

Media is the plural form of medium, which nowadays has touched all aspects of human's life, including education. Every application of media is somewhat unique but in any cases it must be guided by both general principles of learning and the context in which these principles are employed, for the instructional use of media programs are designed intentionally to make the teachinglearning environment more interesting and effective (Locatis \& Atkinson, 1990).

Teaching media can be classified into three categories; visual media, audio media, audio visual media. In this research, the researcher uses audio visual media or projection media named video film as the interaction media, because teaching English using video is believed to be able to motivate the students to pay more attention to the material given.
There is a general consensus among researchers and teacher educators that video can be a valuable tool for supporting teacher learning (Brophy, 2004; Darling-Hammond, 2006; Goldman et al., 2007). Video conveys the complexity and subtlety of classroom teaching as it occurs in real time, with a richness and immediacy that written descriptions or transcripts cannot achieve (Brophy, 2004; Goldman et al., 2007 ).

According to Harmer (2001: 282), using video film as media in teaching learning process has several advantages.

1) When using video film students do not just hearing language, they see it too. This greatly aids comprehension, for example; general meaning and moods are often convoyed through expression, gestures, and other visual clues. Students can imitate some expressions or gesture in spoken language.

2) Video film uniquely allows students beyond their classroom. This is especially useful if they want to see, for example, typical British 'body language' when inviting someone out, or how American speaks to waiters. Video is also of great value ingiving students a chance to see such thing as what of food people eat in other countries, and what they wear. They not only learn about language, but also they can learn about culture of another country.

3) When students use video film themselves they are given potential to create something memorable and enjoyable. In addition students will be enjoy their learning activity. Video film can help them to achieve in understanding the material.

4) For all of the reasons so far mentioned, most students show an increased level of interest when they have a chance to see language in use as well as hear it. It can motivate students in process teaching learning.

It is important for the teacher to choose the suitable video film which is related with the materials. Video has to have a good moral value in order to persuade and motivate students in doing positive things. 
Mastering a large number of vocabulary is very important for foreign language learners. According to Hatch and Brown (1995, p.1), the term vocabulary refers to a list or set of words for particular language or a list of words that individual speakers of language use. Since vocabulary is a list, the only system involved is alphabetical order. The choice in vocabulary selection and methods used in teaching vocabulary are important factors. Vocabulary mastery can be measured by the requirements of generalization (being able to define words) and application (selecting an appropriate use of it). It can be said that vocabulary mastery is a complete skill to understand the stock of words and their meanings of a particular language.

\section{Method}

Classroom Action Research is chosen by the researcher in order to improve the seventh grade students' vocabulary mastery by watching video as the media at SMP Muhammadiyah 1 Jember. The subject of this research was students of VIIc class of SMP Muhammadiyah 1 Jember which totaled 36 students. Ary (2010, p. 513) states that in education; action research can be applied to such areas as curriculum development, teaching strategies, and school reform. Action research in schools is also called practitioner research, teacher inquiry, or teacher research, although the process can certainly be used by other school personnel besides teachers, including coaches, counselors, principals, superintendents, librarians, technology specialists, and other education professionals. The goal of action research in education is to create an inquiry stance toward teaching where questioning one's own practice becomes part of the work and of the teaching culture. According to Arikunto (2010, p. 129) Action Research is "research about something happened in society or the target group, and the result can be directly implemented to those involved. Based on the previous statements above the Classroom Action Research here is research about something that happened in teaching learning process and the result can be directly implemented to the teacher and students in the class.

In implementing the action, the researcher played videos about family and hobby, which suited the lesson plan for the day. All of the videos played in the classroom were downloaded from internet. The next step is observing which means collecting the data to know how the teaching vocabulary using video as media has achieved the target. The effect of the action was always monitored reflectively. The data that need to be collected are quantitative data (score of students) and qualitative data ( student's active participation). In this stage, the researcher used two kinds of instruments, written test and observation checklist. Reflecting was conducted after analizing the result of the first cycle. It is intended to know whether the action is successful or not. In reflecting the action, the researchers collaborate with the English teacher discussing the problems occured and solved them. Then, the result of reflection was used as a guideline to revise the action in the first cycle. Because the requirement above could not be achieved in the first cycle, so the study was continued to the second cycle. The instruments of the research are vocabulary test in multiple choice form, and observation checklist. The vocabulary test was used to measure students vacabulary mastery and the observation checklist used to get the information about students's active participation.

\section{Results and Discussion}

Before the research, a preliminary study was conducted on 15 th July 2018 . Here, interview was done with the English teacher to get information and data about the students problem in the class. Based on the interview and the vocabulary score data from pre test that had been done, there was only 23 students or $63 \%$ of the total number of students got score 
$\geq 70$ in the vocabulary test. The target score of vocabulary mastery is $\geq 70$. This research considered as success if the percentage of students who passed the target score was $75 \%$ and the percentage of students' active participation is $75 \%$.

The percentage of students who passed the test was measured using this formula;

$$
E=\frac{n}{N} \times 100
$$

With:

$E=$ The percentage of the students who achieve the target score of $\geq 70$

$n=$ The total number of the students who achieve the target score

$N=$ The total number of students (Ali, 1993, p. 186)

The students' active participation was measured using the observation checklist as shown in Table 1.

The numbers of indicators of students' active participation indicate the following participation, respectively:

1. Paying attention

2. Asking / Answering Question

3. Working in group

4. Performing the task

The students categorized as active if they fulfill at least 3 indicators above.

After the preliminary study, the researcher prepared several activities before the implementation of the research, such as:

a) Choosing the themes and subthemes

b) Preparing the methods to teach vocabulary by using video

c) Preparing the materials

d) Constructing the lesson plan for the cycle;

e) Preparing the monitoring instruments as well as instrument for evaluation and the scoring set for the evaluation;

f) Constructing the test;

g) Determining the criteria of success;
The action was conducted during school hours in classroom. The researcher plans this research in 2 cycles and 2 meetings plus one test of each cycle. The duration of each meeting was 90 minutes. The first cycle is implemented based on the lesson plan made before the action given to the students, the action in cycle 1 did in the first and second meeting, and the test of cycle 1 did in the third meeting. The teacher acted as an observer while the researcher acted as teacher who taught vocabulary by playing video as the media.

The first cycle divided into two meetings. In the first meeting students was tought using video without subtitle. The video played twice, the action repeat in the second meeting using different video but similar theme. The theme was hobby and family which was suitable with the curriculum for seven grade students. Most of the vocabulary were nouns which is one of seven word classes according to Thornbury (2002:3) "vocabulary has seven word classes those are: nouns, pronouns, verb, adjectives, adverb, prepositions and conjunction". Then the action followed by observing step in the third meeting. The instruments used in the third meeting is vocabulary test which is in multiple choice form. The result of the test showed that only 25 students or $69 \%$ of the students achieve the target score, while 11 students still cannot achive the target score. Moreover the observation checklist was showed that only 20 students or 55\% from the total number who followed the subject actively. Almost half of students did not pay attention, especially the students who sat down at the backside. The students got bored and sleepy. The result suggests that the cycle 1 was considered failed.

From the reflection of cycle 1 , it was found that the target failed to be achived becouse of several factors;

1. the video played without subtitle

2. many new and unfamiliar vocabularies

3. playing the video two times was not enough.

Based on the reflection of cycle 1, some revision to the teaching strategy were 
composed by the researcher and the observer. The revision written as the planning of cycle two. So here is the planning of cycle 2;

1 . The video used for teaching media must be completed with subtitle.

2. The new vocabulary must be drilled.

3. The video played three times followed by some instruction; first, students must watch the video, only watch the video without doing anything else. Second, students must take notes of the vocabulary, that suitable with the theme, hobby and family. Third, students must complete their notes by paying attention to the video and discused with their pair and the teacher.

There were three meetings in cycle 2 . The first and second meeting to implemented the strategy and the third meeeting to test students' vocabulary mastery. The video played in cycle two was diferent with the video in cycle 1 , however it still had the same theme, it was about family and hobby. From 36 students, there were 29 students got 70 and above, and 28 students followed the teaching and learning process actively. This confirms the success of the cycle 2 since there had been $80 \%$ students who had achieved the target score and $77 \%$ students followed the teaching and learning process actively. From the reflection of cycle two it was found that the cycle must be stop because the target score was achieved and the students' active participation increased.

It showed that there was significant improvement in students' achievement and all activities in this cycle run well. It is suitable with Harmer (2002:282), most students show an increased level of interest when they have a chance to see language in use as well as hear it, and when this is coupled with interesting tasks. To sum up, significant improvement at the second cycle was caused by the use of video as a media in teaching and learning process.

\section{Conclusion}

Based on the results of this research and discussion, it can be concluded that the use of video as a media can improve students' active participation and vocabulary mastery. It is proved that by watching the video that is suitable with the theme could attract students' attention and the same time improve their vocabulary mastery.

\section{References}

Ali, H. Muhammad. (1993). Strategi Penelitian Pendidikan. Bandung: Angkasa

Arikunto, Suharsimi. (2013). Prosedur Penelitian. Yogyakarta: Rineka Cipta.

Ary, Donald. (2010). Introduction to Research in Education(eighth edition). United State

Brophy, J. (2004). Using Video in Teacher Education. Bingley: Emerald Group Publishing Limited.

Darling-Hammond, L. (2006). Assessing teacher education: The usefulness of multiple measures for assessing program outcomes. Journal of Teacher Education, 57, 120-138. doi:10.1177/0022487105283796.

Depdikbud. (2016). Permen_tahun 2016_ nomor 22. Kemdikbud; Jakarta

Gavin, D and Hockly, N. (2007). How to Teach English with Technology, England: Longman.

Goldman, R., Pea, R., Barron, B., \& Denny, S. J. (Eds.). (2007). Video research in the learning sciences. Mahwah, NJ: Erlbaum.

Hatch, \& Brown,C. (1995).Vocabulary, Semantics, and Language Education. NewYork: Cambridge UniversityPress.

Harmer, Jeremy. (2001). How to Teach Language. England: Longman. 
(2007). The Practice of English

Language Teaching. New York: Longman.

Locatis, C. N. \& Atkinson, F. D. (1990). Media and Technology for Education \& Training. Columbus, Ohio: Charles E. Merrill Publishing company.

Harji, M.B., Woods, P. C., \& Alavi, Z. K. (2010). The Effect of Viewing Subtitled Videos on Vocabulary Learning. Journal of College Teaching and Learning 7(9). https://doi.org/10.19030/tlc.v7i9.146

Oxford. (2008). Learner's Pocket Dictionary. New York: Oxford University press

Thornbury, Scot. (2002). How to Teach Vocabulary: Routledge. 